Vesa Haapala ja Riikka Rossi

\title{
Sanojen toiset kasvot
}

Kaikki kirjallisuus on jossakin määrin allegorista. Kirjallisuus sanoo yhtä, mutta tarkoittaa toista tai ainakin pitää yllä toisen tarinan ja merkityksen mahdollisuutta. Allegorisuus ja toisin sanominen eivät ole vain runon tai proosan vaan ylipäänsä kielen ominaisuuksia. "Miten sanat ymmärretään, sitä eivät sanat yksin kerro", toteaa Ludwig Wittgenstein kielen luonteesta 1940-luvun lopulla kirjoittamassaan Zettel-katkelmassa. Kärjistäen voisi väittää, että kirjallisuudentutkijoiden työnä on etsiä tekstien "toista" ja tulkita, miten mimeettisen ja kirjaimellisen tason oheen kudotut ulottuvuudet ilmentävät itseään.

"Näkyvän" alle ja oheen kirjoitettu "toinen" tarina ja sen tutkiminen yhdistävät myös tämän Avaimen artikkeleita. Matti Savolainen käsittelee William Faulknerin Absalom, Absalom! -romaanin (1936) hiljennettyä toiseutta, teoksen arvoituksellisen päähenkilön Thomas Sutpenin koloniaalista menneisyyttä Haitilla. Kerrontaan tukahdutettu toiseus on tuttu monesta muustakin koloniaalisia jännitteitä käsittelevästä romaanista, kuten Jane Austenin Kasvattitytön tarinasta (1814) tai Joseph Conradin Pimeyden sydämestä (1902).

Kristina Malmio tarkastelee Solveig von Schoultzin novellin "Även dina kameler" (1965) kolmea intertekstiä Michel Riffaterren Fictional Truth -teoksen teoreettisiin malleihin nojaten. Malmio analysoi, kuinka von Schoultzin novellin arvoituksellisuus, "pinnanalainen teksti" rakentuu ja tematisoituu tekstin tiedostamattoman matriisin vaikutuksesta.

Olli Löytty puolestaan purkaa Arvid Järnefeltin Maa kuuluu kaikille! -pamfletin (1907) otsikkoon sisältyvää kannanottoa sen puolesta, että jokaisella työtätekevällä ihmisellä on luonnollinen oikeus maahan. Löytty tutkii, keitä "kaikkia" Järnefelt pamfletissaan tarkoittaa. Hän osoittaa, miten Järnefeltin kirjoituksessa rakentuva kansakuva purkaa aikakaudelle ominaista säätyhierarkiaa ja keskustan ja periferian vastakkainasettelua.

Malmio lukee siis von Schoultzia intertekstuaalisuuden teorian valossa, Löytyn ja Savolaisen lähestymistapa on kontekstuaalinen ja postkoloniaalinen. Vaikka artikkelien metodiset lähtökohdat ovat erilaiset, yhteistä niille on se, että tulkinnat lähtevät liikkeelle jostakin marginaalisesta yksityiskohdasta, jonka varaan toisen tarinan artiku- 
lointi rakentuu. Kuten Savolainen artikkelissaan kuvaa, Thomas Sutpenin historia paljastuu tiedonmurusten ja huhujen kautta. Romaanin kiertelevä ja "spekuloiva” kerrontastrategia pyrkii peittämään menneen. Von Schoultzin novelli ankkuroituu arkiseen todellisuuteen, mutta sen sisältämät arvoitukselliset kohdat ja mimeettisyyttä rikkovat anomaliat haastavat täydentämään realistisen tekstin aukkopaikkoja ja samalla näkemään tekstin tematiikan uudessa valossa.

Jos kirjallisen tekstin "toiseutta" verrataan edelleen allegoriaan, symbolien ja ylipäänsä kielen ja merkkien monitulkintaisuudet asettavat kirjallisuudentutkijan mielenkiintoisen metodologisen ongelman eteen. Tekstin "toinen" tarina on aina luonteeltaan epävakaa ja hypoteettinen, eikä toiseudesta ole yhtä totuutta. Miten merkityksiltään ambivalentin ja avoimenkin "toisen" tarinan tavoittaminen onnistuu, kun sitä lähestytään tieteen nimissä - objektiivisesti, havaittaviin tosiasioihin nojaten? Vaikka tutkija kuinka perustelisi tulkintansa tekstistä todennettavien seikkojen pohjalta, ajatus "empiirisestä tulkinnasta" kuulostaa nykyisin lähinnä retoriselta mahdottomuuskuviolta. Monet jälkistrukturalistiset teoreetikot ovatkin Friedrich Nietzschen merkkiopin ja vallantahdon ajatusten innoittamina väittäneet, että tekstillä ei ole merkitystä, vaan että merkitys asetetaan tekstiin!

Matti Savolainen tunnustaa ongelman epäsuorasti kuvatessaan artikkelinsa alussa lähestymistapaansa spekulatiiviseksi. Älyllistä ja teoreettista tarkoittavalla, empiirisyyden vastakohdaksi asettuvalla spekulatiivisuudella ei ole ollut hyvä kaiku humanistisessa tutkimuksessa, sillä spekulatiivisuuteen liittyy riskinotto ja käsitteellinen keinottelu. Spekulatiivinen asenne tutkimukseen merkitsee paitsi kyselevää uteliaisuutta myös tutkijan subjektiivista heittäytymistä tuttujen asetelmien ulkopuolelle. Tällaiseen asenteeseen sisältyy monia riskejä. Pienin ei ole tarkoitushakuinen tulkinnallinen manipulointi. Artikkelissaan Savolainen kritisoikin postkoloniaalisen teorian kyseenalaista käyttöä ja sanojen "koloniaalinen" ja "jälkikoloniaalinen” vesittymistä, kun niitä viljellään lähes kaikenlaisen dominoinnin, alistamisen tai hyväksikäytön yhteydessä.

Tulkinnan ehtojen ja käsitteiden käytön pohdintaan ovatkin nykyisin kuuluneet keskustelut tulkinnan ja vallan kytköksistä. Tutkimuskielestä vallitsevaan konsensukseen ei riitä, että tutkijoilla on samoja tai samankaltaisia määritelmiä. Käsitteitä on myös käytettävä samalla tavoin aktuaalisissa tilanteissa ja arvostelmien tulee lähetä kylliksi toisiaan, jotta erilaiset spekulaatiot tulisivat ymmärretyiksi. Joka tapauksessa spekulatiivisuus on tullut tutkimukseen jäädäkseen, jopa myönteisenä käsitteellistä otetta kuvaavana terminä. Spekulatiivisia eivät ole vain feministinen, queerteoreettinen tai postkolonialistinen tutkimus. Yhtä lailla lajiteoreettinen ja intertekstuaalinen tutkimus kuuluvat spekulatiivisuuden alueelle, sillä myös niissä teoreettiset hypoteesit ja mallinnukset määräävät voimakkaasti tulkittavien ilmiöiden hahmottumista.

Spekulatiivisesta toista tarinaa kohti menemisestä on muodostunut keskeinen osa 
kirjallisuustiedettä, tuohan tulkinta aina peliin yhtä lailla lukijan oman tarinan kuin tekstinkin toiseudet. Myös kirjallisuuden jatkuva muutos asettaa tulkinnalle ja tutkimukselle haasteita. "Postmoderni" romaani leikittelee tietoisesti ajatuksella historiasta kertomuksena ja todellisuuden tulkintana. Kun nykykirjallisuuden keskeisenä ideana on ollut "realistisen" romaanin ja sen loogisesti etenevän kerronnan purkaminen, ei mimeettisen tarinatason ja "symbolisen" toisen tason erottaminen toisistaan ole aina yksinkertaista. "Kertoo yhtä ja tarkoittaa toista" -sääntö ei päde nykykirjallisuudessa samoin kuin klassisissa narratiiveissa. Elämme monimielisten alkujen, epäluotettavien kertojien, monien tarinoiden ja avoimien loppujen maailmassa. Mistä "kertovat" Paul Austerin romaanit tai millaiset tasot risteävät Steven Hallin teoksessa Haiteksti?

Tutkijoiden ja opettajien kuulumista kaikkien tuntemaan ensimmäisen tason tarinaan voi tarkastella lukemalla Freiburgin yliopiston englannin kielen ja kirjallisuuden professori Monika Fludernikin haastattelun, jonka Merja Polvinen teki keväällä kirjallisuusteoreetikon vieraillessa Helsingissä. Fludernik, yksi aikamme yliopistovaikuttajista, pohtii sivistysyliopiston mahdollisuuksia ajassa, jossa tulosajattelu määrittää yhä enenevässä määrin myös korkeakoulujen toimintaa. 